\section{MECHANICAL, THERMAL AND DURABLE PERFORMANCE OF WASTES SAWDUST AS COARSE AGGREGATE REPLACEMENT IN CONVENTIONAL CONCRETE}

Ghasan Fahim Huseiena*, Ruhal Pervez Memona, Ziyad Kubbab, Abdul Rahaman Mohd Sama, Mohammad Ali Asaada, Jahangir Mirzac, Uroosa Memond

aschool of Civil Engineering, Faculty of Engineering, Universiti Teknologi Malaysia, 81310 Johor Bahru, Malaysia

bDepartment of Civil Engineering, College of Engineering, Muthanna University, Samawa, 66001, Iraq

cDepartment of Materials Science, Research Institute of HydroQuebec, 1800 Mte Ste. Julie, Varennes, Quebec, Canada, J3X 1 S 1 dCivil Department, Isra University, Hyderabad Campus, Sindh, Pakistan
Article history

Received

16 May 2018

Received in revised form

3 October 2018

Accepted

31 October 2018

Published online

15 December 2018

*Corresponding author fhghasan3@live.utm.my

\begin{abstract}
Wood yields a number of by-products and Sawdust is as useful as others. Sawdust is regarded as a waste material and is effectively utilised as sawdust concrete in the construction of buildings. It is capable to be utilised as light-weight concrete and holds the quality of long duration heat transfer. In this study, three different ratios $(1: 1,1: 2$ and $1: 3)$ volume mix proportions of cement to sawdust were adopted to make sawdust concrete. At varied intervals of 7,28 and 56 days of air curing, thermal and mechanical properties like workability, density, elastic modulus, strength and heat transfer were probed of mentioned sawdust concrete proportions. The resistance to elevated temperatures was also evaluated after 28 days of age; weight loss, residual compressive strength, surface texture and ultrasonic pulse velocity were considered in evaluation process. The findings showed that increase in sawdust volume affected to decrease the workability, strength and elevated temperatures resistance. However, the concrete having higher proportion of sawdust performed competently and well in terms of thermal conductivity. Moreover, a decrease in the heat transfer of sawdust was also observed. Examining the all-embracing mechanical and physical properties, sawdust can be effectively utilised in the construction of buildings.
\end{abstract}

Keywords: Sawdust, coarse aggregate, strength, durability

(c) 2019 Penerbit UTM Press. All rights reserved

\subsection{INTRODUCTION}

For over hundred years, concrete has been most commonly used material in building construction. Normal concrete is a mixture of fine aggregate, water, coarse aggregate and cement. Nowadays, speedy and meteoric development of composite structure stands in need of better concrete performance and a good quality material [1-3]. Though concrete is the most cost effective material but it increases dead load of the building due to its high density [4-6]. If the density of concrete is reduced it can lead to a number of advantages, as it then results in the reduction of the cost of handling, constructability and transportation [79]. In comparison to other industries, natural resources are being more consumed by the construction industry. Increase in public awareness regarding the demands and needs of environmental conservation 
and sustainable development calls much upon the country's construction and building industry to promote its practices to meet the needs of our present generation without retrenching the resources of upcoming generation [10, 11]. For instance, worldwide billions of tons of concrete is produced each year as it is accounted as most essential building material and without it the country's infrastructure is preposterous and unacceptable. In recent years, concrete technology has remarkably achieved breakthroughs and has made advanced progress, which is being massively unnoticed and neglected by the public [12].

The other way to make a concrete lighter in the construction industry is to develop and introduce lightweight concrete (LWC) [13-15]. Recently, due to the ability of reducing the earthquake force and the dead load, the lightweight concrete is being used. Lightweight concrete's density is about $80 \%$ of the normal weight concrete [16]. Ranges for the structural lightweight concrete density are between 1440 and $1840 \mathrm{~kg} / \mathrm{m} 3 \mathrm{c}$. In contrast, normal weight concrete's density values ranges between 2240 and $2400 \mathrm{~kg} / \mathrm{m}^{3}$. Since then, concrete has been admired and favored. Researches are being done to explore the ways of making it light weighted with cost effective feature and high quality insulating properties. In the field of building construction, considerable attention and a number of studies in many countries have been devoted to sawdust concrete as a lightweight concrete. In the Singapore-Malaysia region, to use sawdust in building construction many efforts have been exerted to explore its sustainability as sawdust is abundantly present in such tropical regions and is economical and affordable [4].

Due to low compressive strength, the use of sawdust in concrete is not frequent and is limited. Before it is used, its critical limitations must be taken into consideration and understood. In contrast to these limitations, advantages offered by sawdust are wide and important likewise; it reduces the dead load which is transmitted to the foundation by reducing the considerable amount of structural weight, compared to the other normal weight concrete it is highly economical, its handling, mixing and placing is easier in contrast to other types of concrete, the life of framework is prolonged as it reduces damage by exerting low pressure, its high void ratio results in advanced sound absorbent properties, and due to inclusion of wood aggregates it decreases thermal properties of concrete and results in better thermal insulation $[5,17]$. For the concrete sawdust, reduction in the thermal conductivity increases up to $35 \%$, if a mass percentage of gross wood ranges from 0 to $10 \%$. For the past few years, considerable attention has been granted to the use of sawdust for making lightweight concrete and a great range of studies on structural properties of sawdust have been showing promising and supportive outcomes [16].

On burning or using as a fuel, this product from grinding of the plants comprises of pollution and waste of the environment. In order to investigate the economic value of these materials, maximize resources and minimize the construction cost for the sustainable development; replacement and cogitation with the less expensive and locally available materials are to be questioned for engineering in order to meet above needs. In developing counties, industrialization has evolved a surge in agricultural product along with resultant accumulation of cumbersome and incommodious agro wastes [18]. This pollution evolving from these wastes needs to be taken seriously and for many developing countries is a matter of considerable concern. The one way to cope up with such pollution consequences can be recycling of this waste as a new building material, and also it can compensate the problem of expensive building material faced by many countries these days $[19,20]$.

Nowadays, the critical problem faced by this world is of global warming and for materials consideration use of green materials are prioritized. Further, it can also help in saving the consumption of energy by the reduction of heat transmission of the structural systems like roofing system. The core objectives of this study is to research and observe fresh properties of sawdust concrete, inspect its thermal behavior, explore its mechanical and physical properties and discover the premier mixture proportions for saving the energy i.e. heat transfer. Finally this study evaluated the sawdust concrete to elevated temperatures.

\subsection{METHODLOGY}

\subsection{Raw Materials}

Three Ordinary Portland cement, dry mining sand as fine aggregate and Sawdust as coarse aggregate were used in this study. The basic ingredient of concrete was Ordinary Portland cement. When Portland cement is mixed with water it creates a paste which combines with sand to harden to form concrete. Pavement, building floor or all other precast products use Type I cement which is used for all general purpose construction projects. The specific gravity of the cement used was $2.94 \mathrm{~g} / \mathrm{cm}^{3}$. Table 1 shows percentages of the chemical composition of cement in terms of mass of the constituent oxides used for the experiment.

Table Error! No text of specified style in document. 1 Chemical properties of Ordinary Portland cement (OPC) and sawdust

\begin{tabular}{ccc}
\hline $\begin{array}{c}\text { Oxide composition } \\
\text { by mass (\%) }\end{array}$ & OPC & Sawdust \\
\hline $\mathrm{SiO}_{2}$ & 21.03 & 87.0 \\
$\mathrm{Al}_{2} \mathrm{O}_{3}$ & 6.16 & 2.50 \\
$\mathrm{Fe}_{2} \mathrm{O}_{3}$ & 2.58 & 2.0 \\
$\mathrm{CaO}$ & 64.47 & 3.50 \\
$\mathrm{MgO}$ & 2.62 & 0.23 \\
$\mathrm{Na}_{2} \mathrm{O}$ & 0.34 & - \\
$\mathrm{K} \mathrm{O}$ & 0.61 & 0.01 \\
Loss of ignition & 1.73 & 4.76 \\
\hline
\end{tabular}


Natural sand, the fine aggregate or sand is the important materials that need to be used in the concrete mix design. Uncrushed fine aggregate were used in this research. The fine aggregate must be sure that no dust and impurities before the mixing process, thus the strength of the concrete will not affect. The aggregate needs to be clean in order to have productive concrete mixture. Concrete deterioration can be caused by the fine materials. The locally available natural river sand with fineness modulus of 2.3 was used as a fine aggregate. This study used 100 percent passing sieve No. $4.75 \mathrm{~mm}$ fine aggregate of natural beach sand. As the sand had moisture so it was dried in oven too.

Sawdust is wasting form of wood as it is obtained in the process of sawing of wood. This research used sawdust which is shown in Figure 1 and was obtained from local wood factory, "Syarikat Kilang Papan Chong, Wah San Bhd No.6013", is local-agro waste; it was try to ensure that it is all from one source (Kempas -type of wood/tree) with density $174 \mathrm{~kg} / \mathrm{m}^{3}$.

The chemical composition of sawdust presented in Table 1. It was observed the SiO2 is the most composition of sawdust with $87 \%$ from total mass. Comparing to OPC, sawdust showed lower content of $\mathrm{CaO}$ and $\mathrm{Al} 2 \mathrm{O} 3$. However, the loss of ignition (LOI) is higher than OPC and presented $4.76 \%$ comparing to $1.73 \%$ of OPC.

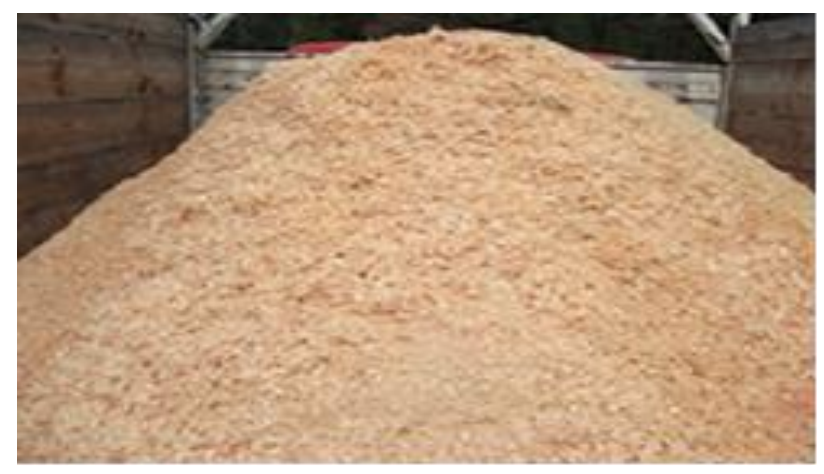

Figure 1 Wooden Sawdust

\subsection{Mix Design}

The concept of concrete mixture design was to determine the required proportion of each constituent, which include; cement, sawdust, fine aggregate, and water. This would produce concrete possessing the specified properties such as workability, strength, durability and economical. The mixture proportions of the sawdust concrete were determined according to the BS specifications and guidelines. Nine specimens were tested for fresh and hardened properties of sawdust at 7 days as trial mixtures. Three concrete mixtures were tested with cement to sawdust ratio 1:1, 1:2 and 1:3 with the water to cement ratio $0.65,1$ and 1.4 respectively. The proportions of concrete mixtures by volume are summarized in Table 2. The ingredients of concrete were thoroughly mixed in a mixer machine till uniform consistency was achieved. The concept of concrete mix design was to determine the required proportion of each constituent, which include; cement, water, fine aggregate and sawdust.

Table 2 Details of mixture proportions by volume

\begin{tabular}{cccc}
\hline Name of the & \multicolumn{3}{c}{ Specimen ID } \\
\cline { 2 - 4 } constituents & SC 1 & SC2 & SC3 \\
\hline Cement & 1 & 1 & 1 \\
Sawdust & 1 & 2 & 3 \\
Sand & 1 & 1 & 1 \\
W/C & 0.65 & 1 & 1.4 \\
\hline
\end{tabular}

\subsection{Preparation of Specimens}

Specimens for fresh and hardened properties were sampled and prepared. Specimens were placed after the fresh properties tests. Following is the procedure for sampling, placing and curing. The number, types, sizes, shapes and purposes of the specimens are summarized in Table 3. Cement, Sawdust, fine aggregates (sand) and water were weighted according to the mixture proportions by volume.

Table 3 Summarized view of the specimens

\begin{tabular}{|c|c|c|c|}
\hline No & $\begin{array}{l}\text { Purpose of } \\
\text { Tests }\end{array}$ & $\begin{array}{l}\text { Shapes and Size } \\
\qquad(\mathrm{mm})\end{array}$ & $\begin{array}{c}\text { Total } \\
\text { number of } \\
\text { specimens }\end{array}$ \\
\hline 1 & $\begin{array}{l}\text { Compressive } \\
\text { strength and } \\
\text { elevated } \\
\text { temperatures }\end{array}$ & $\begin{array}{c}\text { Cube } \\
(100 \times 100 \times 100)\end{array}$ & 48 \\
\hline 2 & $\begin{array}{l}\text { Split tensile } \\
\text { strength and } \\
\text { Modulus of } \\
\text { elasticity }\end{array}$ & $\begin{array}{c}\text { Cylinder } \\
(100 \varphi \times 200)\end{array}$ & 35 \\
\hline 3 & $\begin{array}{l}\text { Flexure } \\
\text { strength }\end{array}$ & $\begin{array}{c}\text { Prism } \\
(100 \times 100 \times 500)\end{array}$ & 27 \\
\hline 4 & Heat transfer & $\begin{array}{l}\text { Cylinder } \\
(150 \varphi \times 300)\end{array}$ & 3 \\
\hline
\end{tabular}

Sawdust, before its mixing, was treated. The process of sawdust treatment included soaking the sawdust for one hour in container filled with water and then for the draining of water from sawdust it was kept 15 minutes on mesh as shown in Figure 2.
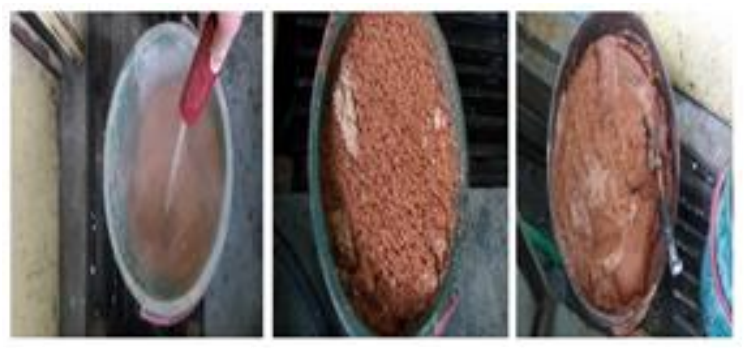

Figure 2 Treatment of Sawdust Concrete 
Batching was proceeded by placing all of the constituents, cement, and sand respectively inside the mixer. First of all sand and cement was mixed, and then during their mixing sawdust was added. Before the addition of water, the uniformity of all mixing constituents was achieved. Specimens were prepared using steel molds properly designed. According to British Standard (BS) and ASTM standards. In this study, there were three batches of concrete specimens, First batch for cement to sawdust ratio 1:1, second batch for cement to sawdust ratio $1: 2$ and third batch for cement to sawdust ratio 1:3, in all batches ration for sand was 1 and as in treatment sawdust absorb water, that amount of water was subtracted or added in water cement ratio. Compaction table was used for compaction of sawdust concrete in specimens. After completed the casting, all the samples were covered by polythene sheets at room temperature for 24 hours then the molds were removed and samples were placed in a covered place so no water touch the samples in the lab according to ASTM C192/C192M standard specifications. Cubes, cylinders, and prisms all of the specimens were cured in air for 7, 28 and 56 days.

\subsection{Test Program}

\subsubsection{Workability Test}

In order to calculate fresh concrete's workability, the slump test was conducted during the casting of concrete. For each batch concrete i.e. LWC and normal concrete, the test was performed accordance to BS EN 12350-2-2009. Using a firmly help slump cone and with the help of a tempting rod the concrete was placed and compacted in three layers for 25 times. The excess concrete at the top was struck off and the mould was lift up carefully in vertical direction and the cone is upturned and place beside the mixture. The slump is the difference in the height between the up turned cone and the uppermost part of the slumped concrete recorded in $\mathrm{mm}$.

\subsubsection{Test on Harden Sawdust Concrete}

The Harden properties of sawdust concrete were investigate in this study based on compressive strength, split tensile strength and flexural strength test at the age of 7,28 and 56 days. Tests were done by casting cubes, cylinders, and prisms from the representative samples of sawdust concrete. As well as the density for the concrete cubes samples were calculated by measuring the weight of each specimen using the weigh scale. Density was calculated by dividing the mass of the concrete derived from the cube samples by the volume of the cube samples $(\rho=m / v)$. The compression test is an important concrete test to determine the strength development of the concrete specimens. Uniaxial compression test was carried out on cubic specimens. Compressive strength tests conducted according to BS
1881-116 are performed on the three cube specimens at the ages of 7, 28 and 56days. The standard test cylinders according to ASTM C496 / C496M were used to perform the split tensile test. This was done on total 27 numbers of specimens 9 for each day at the age of 7, 28 and 56 days. The failure mode also evaluated in this study. Flexural strength test were done according to BS EN 12390-5 of prism specimen having dimension of $100 \times 100 \times 500 \mathrm{~mm}$ was tested under three-points load by using the flexural testing machine at the age of 7,28 and 56 days. The load was recorded up to failure.

The elastic modulus test is performed on cylindrical specimens at the age of 28 days of curing and test was according to ASTM C469. The purpose of this test is to calculate the modulus of elasticity of the concrete. The compressive strength value is obtained from the compressive strength test that was conducted before to be used in the elastic modulus test. The surface of the cylindrical specimens had been clean so that the specimens have smooth, parallel, uniform bearing surfaces that are perpendicular to the applied axial load during the test. The specimens were not capped, because the surface of specimen was not strong enough as normal concrete. After that, two strain gauges were attached to the specimen with each strain gauge was placed parallel to each other and places at the middle from the vertical height of the specimens. The specimen then was placed on the lower platen of the testing machine. The strain and load values were obtained when all the strain gauges were connected to a data logger and load cell. The different percentages between the strains reading were allowed about $15 \%$ to each other. The specimen was imposed to the load with the rate of $0.01 \mathrm{kN} / \mathrm{s}$ until one third of the ultimate load that was obtained before from the compressive strength test of the companion specimen. After that the specimen was unloaded back to its initial load. The strain reading was taken every $5 \mathrm{KN}$ of increment and decrement of load. The specimens were loaded until reached onethird of ultimate load and unloaded three times before the specimen was loaded until it failed.

\subsubsection{Heat Transfer Test}

Cylinder specimen of $150 \mathrm{~mm}$ diameter and $300 \mathrm{~mm}$ height was used to conduct heat transfer test. After casting for 28 days, drying surfaces of sample specimens were covered with a thin plastic sheet to protect it from excessive entrance of water. The thermocouple was protected from sudden impacts by the use of a PVC pipe having $2 \mathrm{~cm}$ diameter as shown in Figure 3. At $34^{\circ} \mathrm{C}$ of water temperature all the samples were put in the water tank and the temperature got increased to $100{ }^{\circ} \mathrm{C}$. When the test got started the first measurement and recording of samples were taken and the temperature was continued up to $100^{\circ} \mathrm{C}$ throughout. After turning the heater, the inside temperature of the samples was recorded by computer, data logger and $\mathrm{K}$ thermocouple. On adding sawdust concrete into the 
water tank, heat was raised by the heater that ultimately resulted in the increase of the water volume temperature. During the first 24 hours until $100^{\circ} \mathrm{C}$ of water, the increase in temperature was monitored with close intervals. However measuring the transfer of heat was later monitored with rather frequents until the temperature dropped close to boiling water.

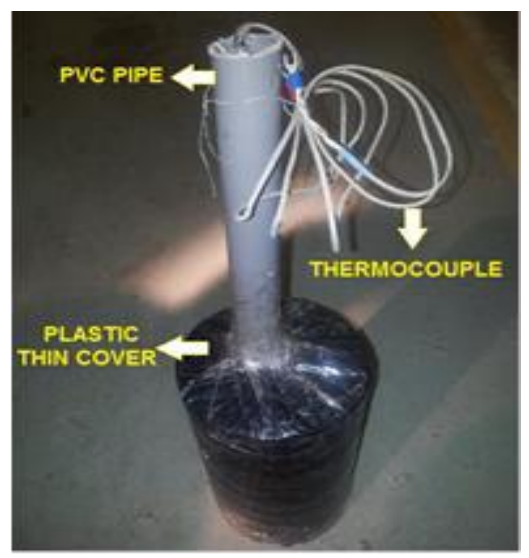

Figure 3 Sample covered with plastic for heat transfer test

\subsubsection{Elevated Temperature Resistance Test}

The test was conducted on the sawdust concrete specimen and control specimen of (100mmx100mmx100mm) cube after 28th days of curing, according to ASTM El 19, an electric furnace was used to place the specimens, where an increase to desired temperature at a rate of $10{ }^{\circ} \mathrm{C} / \mathrm{min}$ was gained. The exposure to real life structural conditions was simulated by keeping the specimens after having desired temperature in the furnace for one hour. After shutting off the power, in order to prevent thermal shock the specimens were still kept in furnace until the room temperature was achieved. The specimens were removed when room temperature was achieved. The test specimens were subjected to varied temperatures of $200,400,600$ and $800^{\circ} \mathrm{C}$ as shown in Figure 4 . At the room temperature, properties like UPV, weight loss and residual compressive strength of control and sawdust concrete specimens were compared to the properties. Thereafter, for each ratio of sawdust concrete and control specimen the residual strength, weight loss and UPV was determined before and after heating. Three specimens of each ratio were tested at different temperatures of $200^{\circ} \mathrm{C}, 400^{\circ}$ ddand the reduction of compressive strength. After the specimens were cooled, the color change and crack patterns were inspected on the surface of control and sawdust concrete specimen. Using a precision balance, weight losses of the specimens were weighed.
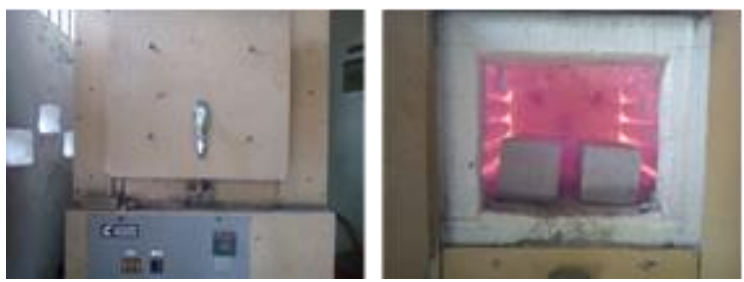

Figure 4 Electric furnace showing concrete specimens

\subsection{RESULTS AND DISCUSSION}

\subsection{Workability}

From Slump test was conducted to determine the workability of the fresh concrete. In the other word, it for measured the consistency of the concrete in the specific batch. The result of slump test was shown in Figure 5. The results show that all the slumps of fresh sawdust concrete are ranging between the limit of 30 to $60 \mathrm{~mm}$. It could be observed that using lightweight aggregate reduced the slump value due to water absorption of lightweight aggregates. Further the results state that slump value decreases with the addition of sawdust, thus workability is decreased by the sawdust.

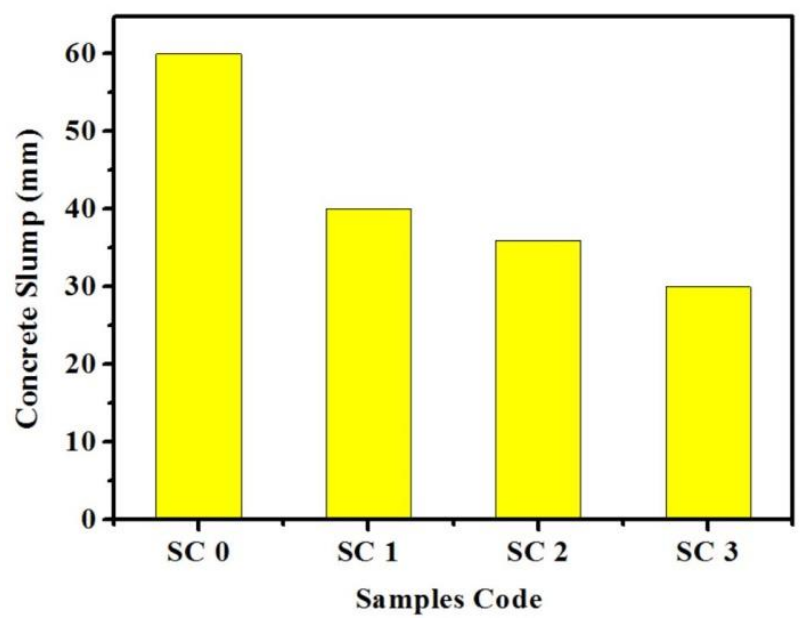

Figure 5 Slump values of sawdust concrete

\subsection{Density}

The different cement to sawdust ratio along with density of sawdust concrete is demonstrated in Figure 6. To determine the 7,28 and 56 days density of the sawdust concrete, cube sawdust concrete specimens with dimensions of $100 \mathrm{~mm} \times 100 \mathrm{~mm} \times 100 \mathrm{~mm}$ were made using varied cement sawdust ratio 1:1, 1:2 and 1:3. The main objective was to explore sawdust concrete with a higher density which results in better mechanical properties for the lightweight concrete. The density range limit for the lightweight aggregate is $1000 \mathrm{~kg} / \mathrm{m}^{3}$ to $1800 \mathrm{~kg} / \mathrm{m}^{3}$ and for normal weight 
concrete is $2200 \mathrm{~kg} / \mathrm{m}^{3}$ to $2600 \mathrm{~kg} / \mathrm{m}^{3}$. Sawdust concrete got all its density range in lightweight concrete but the cement sawdust ratio 1:1 has more density among all in 7, 28 and 56 days.

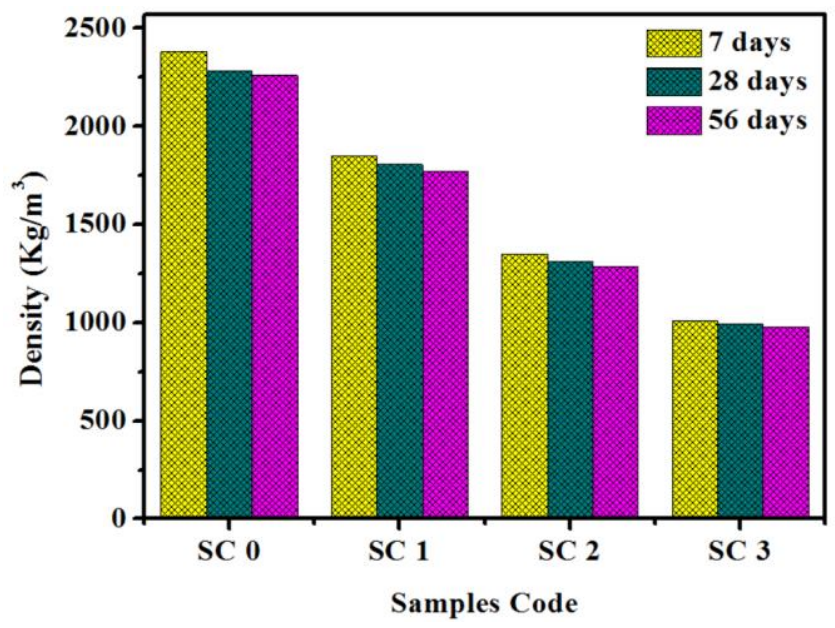

Figure 6 Density of sawdust concrete cubes

\subsection{Ultrasonic Pulse Velocity}

The effect of sawdust replaced of coarse aggregate on ultrasonic pulse velocity (UPV) are presented in Figures 7. It was observed the UPV value trend to decrease with content of sawdust increase. UPV was dropped from $3670 \mathrm{~m} / \mathrm{s}$ to 3200,2150 and $1150 \mathrm{~m} / \mathrm{s}$ after content of sawdust increased from 0 to $1 ; 1,1: 2$ and 1:3 cement to sawdust ratio respectively. With the increase in sawdust content the porosity and density of concrete dropped and effect on UPV values.

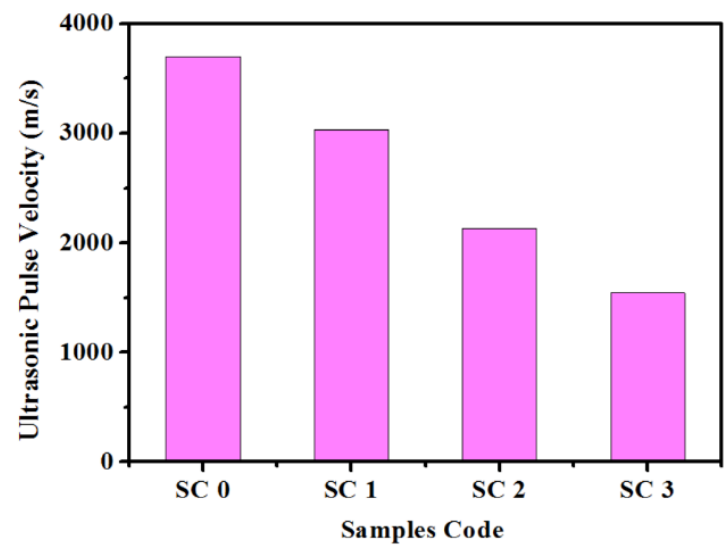

Figure 7 UPV of sawdust concrete cubes

\subsection{Compressive Strength}

The compressive strength of sawdust concrete was tested at the age of 7,28 and 56 days up to curing. Due to the continuity of hydration process the increment strength with age was resulted. It is obvious that with the addition of more sawdust compressive strength is lowered at the very earlier age but gradually it will increase at later age of concrete. The relationship shared by curing period of concrete and average compressive strength with $0.65,1$ and 1.4 water/cement ratios are shown in Figures 8 . At 56 days, for 1:1 cement to sawdust ratio sample maximum average compressive strength was recorded for 19.53 MPa. The samples containing 1:3 of cement sawdust in earlier stage resulted in significant amount of strength reduction but it increased with age.

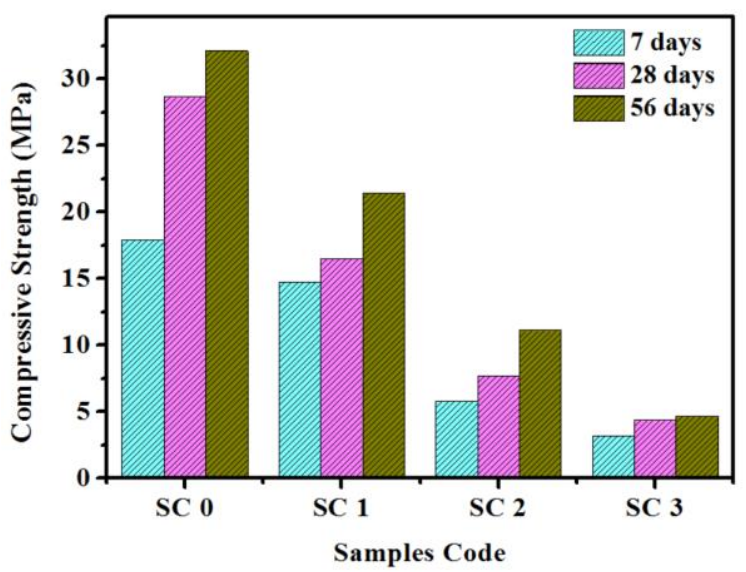

Figure 8 Compressive strength of sawdust concrete

\subsection{Splitting Tensile Strength}

$100 \mathrm{~mm}$ diameter and $200 \mathrm{~mm}$ height Cylinder specimens were tested to determine indirect tensile strength of sawdust concrete. Figure 9 shows the tensile strength test results of sawdust concrete at 7, 28 and 56 days. A similar trend like that of the compressive strength was observed for split tensile strength development in sawdust containing samples. The split tensile strength of sawdust concrete was low. However, samples with 1:1 of cement to sawdust shown a good strength. Highest strength of $4.1 \mathrm{MPa}$ was noted for $1: 1$ of cement to sawdust with 0.65 water to cement ratio.

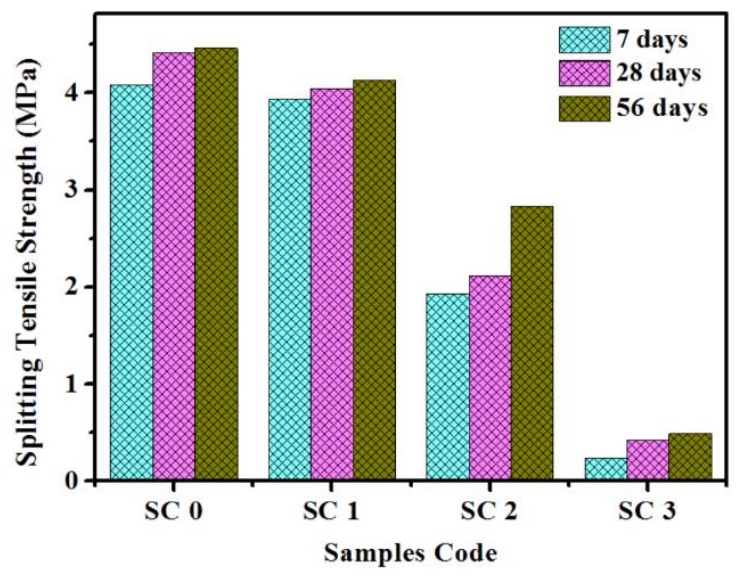

Figure 9 Split tensile strength of sawdust concrete 


\subsection{Flexural Strength}

Figure 10 shows the result obtained from the flexural strength test. At the age of 7, 28 and 56 days, recording of maximum load sustained was taken and calculation of the average flexural strength was done. The gain in strength with $0.65,1$ and .4 water/cement ratio was noted. The same trend was followed by the flexural strength of concrete specimen as followed by tensile strength and compressive strength, the flexural strength decreases with the increased amount of sawdust but at the later ages the graph is illustrating the increase in tendency of $1: 1,1: 2$ and $1: 3$ ratio of cement sawdust concrete. After 56 days, the specimen comprising 1:3 ratio cement sawdust shows lowest strength of $0.77 \mathrm{MPa}$ and $1: 1$ ratio cement sawdust showed the highest strength of $5.77 \mathrm{MPa}$.

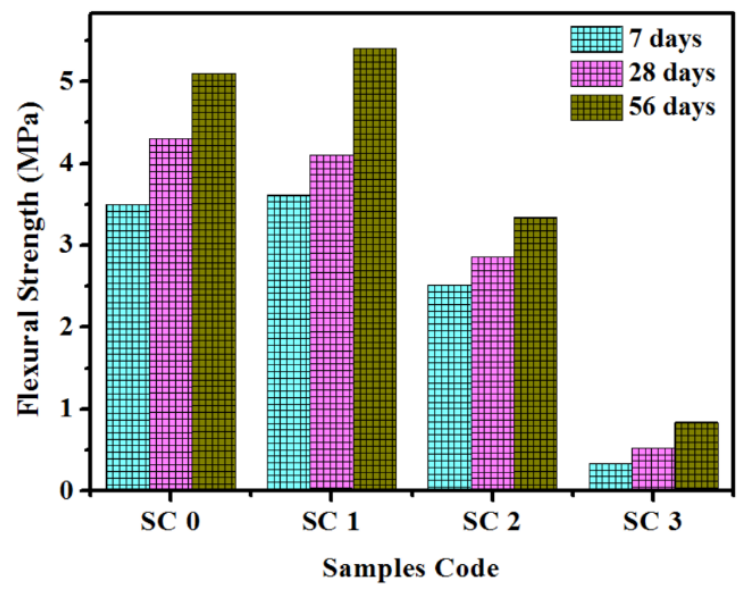

Figure 10 Flexural strength of sawdust concrete

\subsection{Modulus of Elasticity}

Elastic modulus test was carried out on the cylindrical specimens at the age of 28 days. Three cyclic loading with each cyclic limit was one-third of its ultimate load that obtained from compressive strength of companion cylindrical specimen was conducted. After the third cyclic, the load was increased until failure. The elastic modulus of concrete was obtained from the graph of stress versus strain by drawing the best fit line from the graph. The slope of the graph represents the value of elastic modulus is secant modulus. The results of elastic modulus of sawdust concrete were represented in graphical form as shown in Figure 11.

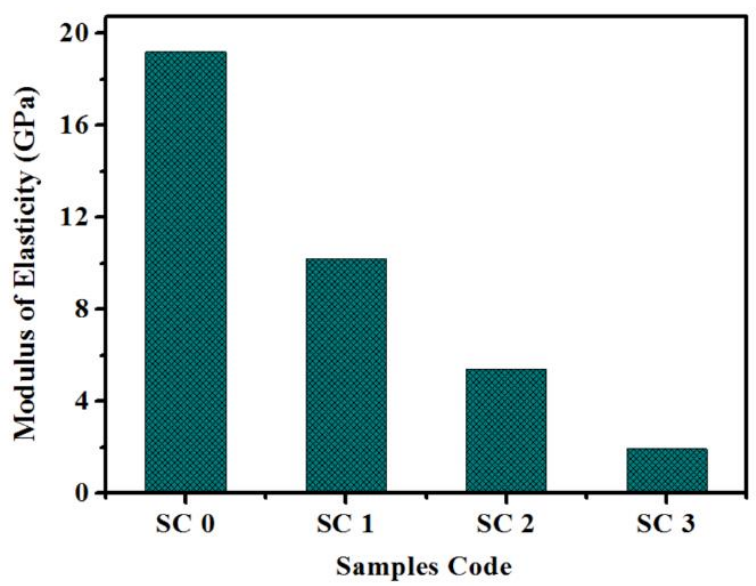

Figure $11 \mathrm{MoE}$ values of sawdust concrete

\subsection{Heat Transfer Test}

The results of variation of the heat transfer versus time were recorded for the different ratio of cement sawdust concrete and presented in (Table 3). It has been observed that during the initial stage, the temperature rise due to heat of hydration of all the specimens was approximately equal Figure 12. However, as testing time increased the influence of sawdust on heat transfer was observed. The specimens containing 1:3 cement to sawdust demonstrated lower heat rise as compared to the 1:1 and 1:2 sample. In contrast to the 1:1 and 1:2 cement sawdust, 1:3 ratio was capable of reducing rise in total temperature. However, during the experimental time 1:1 sawdust concrete yielded more heat transfer even though the initial temperature of water was constant.

Table 4 Values of heat transfer of sawdust concrete

\begin{tabular}{cccc}
\hline Properties & \multicolumn{3}{c}{ Cement-sawdust ratio } \\
\cline { 2 - 4 } & $1: 1$ & $1: 2$ & $1: 3$ \\
\hline Initial & 27.9 & 28.1 & 27.8 \\
Temperature $\left({ }^{\circ} \mathrm{C}\right.$ ) & 100 & 100 & 100 \\
$\begin{array}{c}\text { Peak temperature }\left({ }^{\circ} \mathrm{C}\right) \\
\text { Time to reach } 100^{\circ} \mathrm{C} \\
\text { (Hours) }\end{array}$ & 45 & 93 & 160 \\
\hline
\end{tabular}




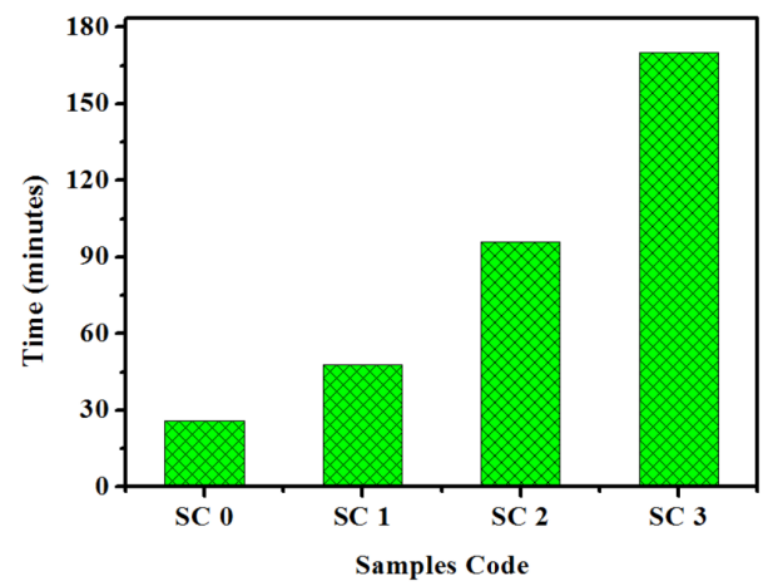

Figure 12 Heat transfer hours of sawdust concrete

\subsection{Elevated Temperature Resistance}

The results of the residual compressive strength of control specimen and sawdust concrete are presented in Figure 13. It shows that the residual compressive strength of sawdust concrete, decreased steadily with increasing temperature. On the basis of the outlook of residual compressive strength obtained at elevated temperature, temperature effect analysis has been categorized into four temperature regions with varied temperature regions, named as 1 (27$\left.200^{\circ} \mathrm{C}\right), 2\left(200-400^{\circ} \mathrm{C}\right), 3\left(400-600^{\circ} \mathrm{C}\right)$ and 4 (600$\left.800^{\circ} \mathrm{C}\right)$.

During these phenomena observation the entire regime was kept cool. In the first and second region, decrease in the residual compressive strength within the cement matrix can be accredited to gradual dehydration, which in turn changes the physical characteristics of the concrete from a saturated surface to a dry state. At the temperatures above $450^{\circ} \mathrm{C}$, the decomposition of calcium hydroxides and the dehydration of calcium silicate hydrates $(\mathrm{C}-\mathrm{S}-\mathrm{H})$ was resulted which in turn resulted a sharp drop in the residual compressive strength in the third region. In the second region, increase in the residual compressive was noted for the control specimens. The mentioned result could be due to an increase in building properties and loss of water of $\mathrm{C}-\mathrm{S}-\mathrm{H}$ from the specimen leading to a pre-hardening state.

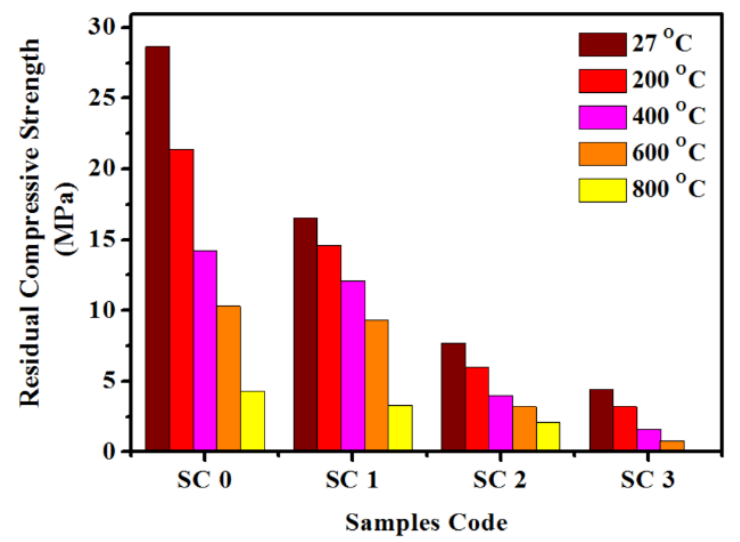

Figure 13 Residual comprresive stregth at elevated temperature

The effect of elevated temperature on the weight loss of sawdust concrete and control specimen are illustrated in Figure 14. On the basis of the outlook of residual weight and compressive strength obtained at elevated temperature, temperature effect analysis has been categorized into four temperature regions with varied temperature regions, named as $1\left(27-200^{\circ} \mathrm{C}\right), 2$ $\left(200-400^{\circ} \mathrm{C}\right), 3\left(400-600^{\circ} \mathrm{C}\right)$ and $4\left(600-800^{\circ} \mathrm{C}\right)$. The great lost in the weight of the test samples can be observed with the increase in temperature. In control specimen and sawdust concrete, there was the minimum weight loss up to the temperature of $200^{\circ} \mathrm{C}$. The reason for this loss in the region is because of the moisture movement from concrete surface to the surrounding environment. In the second region, the sawdust concrete 1:3 exhibited the highest weight loss (15.6\%) comparing to other mixtures. The raise of maximum weight loss of $24.8 \%$ was noted in sawdust concrete 1:3 in the last region having temperature ranging between 600 to $800^{\circ} \mathrm{C}$. This weight loss can be the result of mechanical properties and changes in the stiffness of the concrete when exposed to high temperature. Decomposition of $\mathrm{Ca}(\mathrm{OH})_{2}$ and evaporation of water in C-S-H structure causes loss of binding properties in cement paste. However, the sawdust particles withheld a large number of moisture content which can possibly result in weight loss in sawdust concrete. 


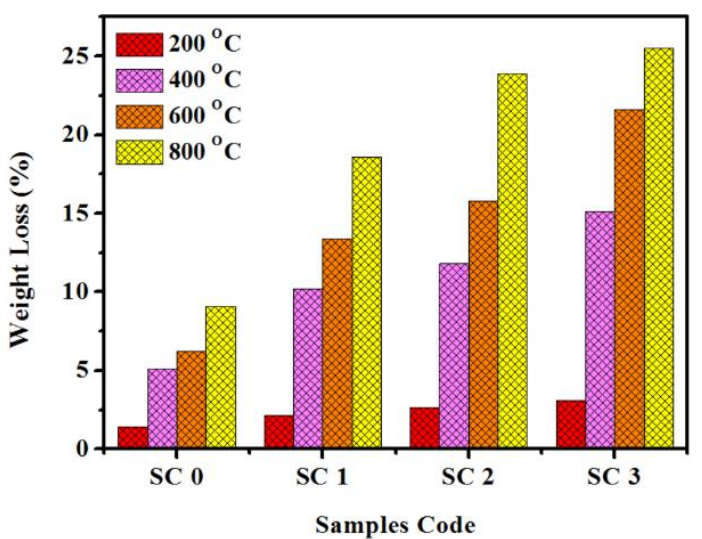

Figure 14 Weight loss of sawdust concrete at elevated temperature

Figure 15 presents the variations in the ultrasonic pulse velocity (UPV) of the concrete which was exposed to the deputed temperatures. As the temperature got higher, all the test specimens exhibited lower velocities, but on the other side higher UPV of concrete specimens was observed at initial temperature. At the beginning of rising temperature of $27^{\circ} \mathrm{C}$, UPV value of control concrete specimen, cement sand ratio 1:2, 1:3, 1:4 for example, was 3704 $\mathrm{m} / \mathrm{s}, 3449 \mathrm{~m} / \mathrm{s}, 3030 \mathrm{~m} / \mathrm{s}$ and is considered good and fair respectively in terms of concrete quality. UPV value for sawdust concrete ratio $1: 1,1: 2$ and $1: 3$ at $27^{\circ} \mathrm{C}$ was $3030 \mathrm{~m} / \mathrm{s}, 2000 \mathrm{~m} / \mathrm{s}$ and $1428 \mathrm{~m} / \mathrm{s}$ respectively which conceder as fair, poor and very poor concerning concrete quality. UPV values between 2857 and 2500 $\mathrm{m} / \mathrm{s}, 1818$ to $1538 \mathrm{~m} / \mathrm{s}$ and 1250 to $0 \mathrm{~m} / \mathrm{s}$ were gained in a temperature ranging between $200-400{ }^{\circ} \mathrm{C}$, that can be regarded as poor and very poor quality concrete for sawdust concrete ratio 1:1, 1:2, 1:3 respectively. The UPV values obtained for control specimen ratio $1: 2$, $1: 3,1: 4$ at the range of $200-400^{\circ} \mathrm{C}$ was ranging from $3571 \mathrm{~m} / \mathrm{s}$ to $3334 \mathrm{~m} / \mathrm{s}, 3225 \mathrm{~m} / \mathrm{s}$ to $2941 \mathrm{~m} / \mathrm{s}$ and $2778 \mathrm{~m} / \mathrm{s}$ to $2000 \mathrm{~m} / \mathrm{s}$ respectively. Nevertheless, in the $600-800^{\circ} \mathrm{C}$ temperature range, the results obtained for both sawdust concrete and control specimen are considered very poor regarding quality. Deterioration and stagnation in the microstructure of the concrete resulted in the reduction in the change of the velocity.

Several researchers [21-25] attributed that temperature above $450^{\circ} \mathrm{C}$ results in such type of change to degradation of the $\mathrm{C}-\mathrm{S}-\mathrm{H}$ gel, which outturns increase in the amount of air voids in the concrete and ultimately the decrease in the transmission speed of sound waves through the specimen is resulted.

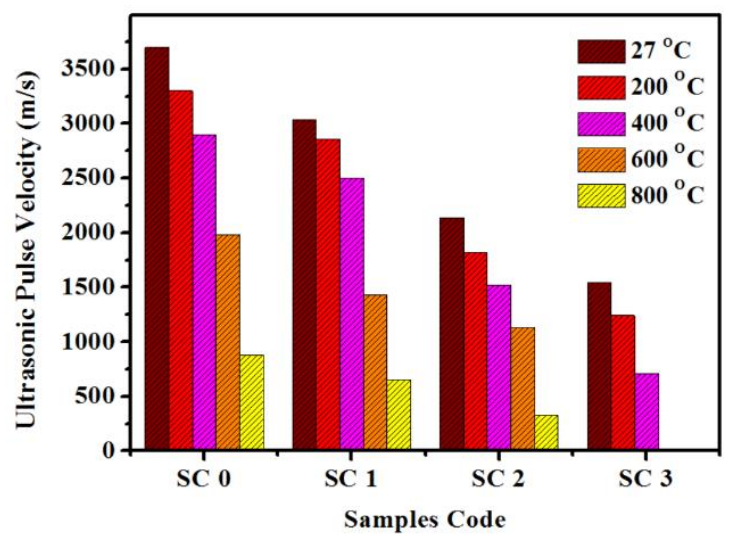

Figure 15 UPV values of sawdust concrete at elevated temperature

When the concrete was exposed to higher temperatures, the initial assessment in terms of physical appearance of concrete was done by means of colour, shape and surface outlook. The deformation suffered by the concrete may not yield realistic structural information by the appearance but it would come with the notion of the general condition of the specimen. Many changes were noted when concrete specimen was in the fire resistance process.

At room temperature $27^{\circ} \mathrm{C}$ and $200^{\circ} \mathrm{C}$ the colors of sawdust concrete was light brown and color of control specimen was moist-gray, with smooth surfaces and perfect edges as shown in Figure 16 These features were continued up to a temperature of $400^{\circ} \mathrm{C}$ as shown in figure 16 but as shown in Figure 16 , at $600^{\circ} \mathrm{C}$, a light gray for the control specimen and a dark gray color for the sawdust concrete, both without smooth and perfect edges, small cracks were absorbed in control specimen but no cracks in sawdust concrete . At $800^{\circ} \mathrm{C}$, a whitish-grey color for the control specimen with small cracks on the surface but sawdust concrete was light gray with ash on the surface which is because of the burning of wood sawdust, both with rough edges, were perceived for the specimens at $800^{\circ}$.

Control specimens at $200^{\circ} \mathrm{C}$ has not significant effect on texture as shown in Figure 16 but at the $400^{\circ} \mathrm{C}$ temperature as shown in figure its color change from gray to light brown Control specimen developed small cracks on the surface at the temperature $600^{\circ} \mathrm{C}$ and $800^{\circ} \mathrm{C}$, while the sawdust concrete suffered from big cracks. A common consensus elaborates that formation of micro-cracks in concrete is linked with lower strength development. 


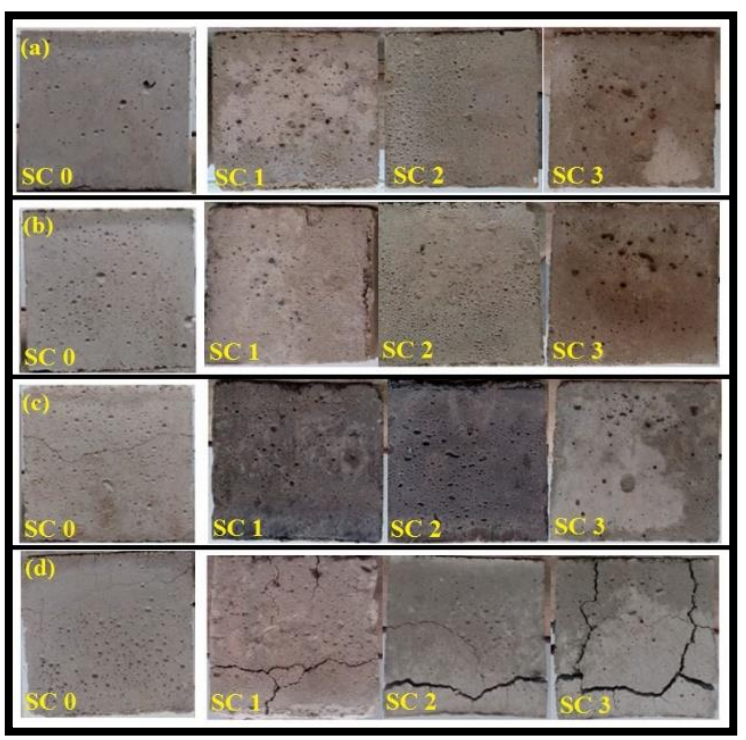

Figure 16 Surface texture of the sawdust concrete samples ratio exposed to (a) $200^{\circ} \mathrm{C}$ (b) $400^{\circ} \mathrm{C}$, (c) $600^{\circ} \mathrm{C}$ (d) $800^{\circ} \mathrm{C}$

\subsection{CONCLUSION}

A set of varied experiments investigated mechanical and thermal properties of sawdust concrete. The present study has drawn the following possible conclusions: It is observed that the workability of sawdust is low with slump ranging between $30 \mathrm{~mm}-$ $40 \mathrm{~mm}$. Sawdust has got less density in comparison to other normal concretes which let it be regarded as light weight concrete. The 1:1 ratio exhibited outstanding performance in terms of strength gain among all three ratios. Contrary, though ratio 1:3 got lower strength gain, but it yielded best results regarding heat transfer. Thus, increase in sawdust content lowered the heat transfer.

\section{Acknowledgment}

The authors would like to thank the support provided by Universiti Teknologi Malaysia in the form of providing equipment and materials for experimental work.

\section{References}

[1] Kovler, K. and Roussel, N., 2011. Properties of Fresh and Hardened Concrete. Cement and Concrete Research. 41 (7): 775-792.

[2] Huseien, G. F., Mirza, J., Ariffin, N. F. and Hussin, M. W. 2015 Synthesis and Characterization of Self-healing Mortar with Modified Strength. Jurnal Teknologi. 76(1): 195-200.

[3] Rath, B., Deo, S. and Ramtekkar, G. 2017. Durable Glass Fiber Reinforced Concrete with Supplimentary Cementitious Materials. International Journal of Engineering-Transactions A: Basics. 30(7): 964.

[4] Memon, R. P., Awal, A. A., Sam, A. R. M. and Achakzai, L., 2016. Mechanical and Thermal Properties of Sawdust Concrete. Doctoral Dissertation. Universiti Teknologi Malaysia.
[5] Memon, R. P., Achekzai, L. and Mohd, A. R. 2018 Performance of Sawdust Concrete at Elevated Temperature. Jurnal Teknologi. 80(1): 165-171.

[6] Reddy, V. S. G. and V. R. Rao. 2017. Eco-friendly Blocks by Blended Materials. International Journal of Engineering. 30(5): 636-642.

[7] Adebakin, I. H., Adeyemi, A. A., Adu, J. T., Ajayi, F. A., Lawal, A. A. and Ogunrinola, O. B. 2012. Uses of Sawdust as Admixture in Production of Low-Cost and Lightweight Hollow Sandcrete Blocks. Am. J. Sci. Indus. Res. 3: 458-463.

[8] Shahba, S., Ghasemi, M. and Marandi, S. M. 2017. Effects of Partial Substitution of Styrene-Butadiene-styrene with Granulated Blast-furnace Slag on the Strength Properties of Porous Asphalt. International Journal of EngineeringTransactions A: Basics. 30(1): 40.

[9] Thrinath, G. and Kuma, P. S. 2017. Eco-friendly Self-curing Concrete Incorporated with Polyethylene Glycol as Selfcuring Agent. International Journal of EngineeringTransactions A: Basics. 30(4): 473-480.

[10] Huseien, G. F., Mirza, J., Ismail, M. and Hussin, M. W. 2016. Influence of Different Curing Temperatures and Alkali Activators on Properties of GBFS Geopolymer Mortars Containing Fly Ash and Palm-oil Fuel Ash. Construction and Building Materials. 125: 1229-1240.

[11] Khankhaje, E., Hussin, M. W., Mirza, J., Rafieizonooz, M. Salim, M. R., Siong, H. C. and Warid, M. N. M. 2016. On Blended Cement and Geopolymer Concretes Containing Palm Oil Fuel Ash. Materials \& Design. 89: 385-398.

[12] Hussein, A. A., Jaya, R. P., Hassan, N. A., Yaacob, H. Huseien, G. F. and Ibrahim, M. H. W. 2017. Performance of Nanoceramic Powder on the Chemical and Physical Properties of Bitumen. Construction and Building Materials. 156: 496-505.

[13] Mo, K. H., Alengaram, U. J., Visintin, P., Goh, S. H. and Jumaat, M. Z. 2015. Influence of Lightweight Aggregate on the Bond Properties of Concrete with Various Strength Grades. Construction and Building Materials. 84: 377-386.

[14] Huseien, G. F., Ismail, M., Tahir, M. M., Mirza, J., Khalid, N. H. A., Asaad, M. A., Husein, A. A. and Sarbini, N. N. 2018. Synergism between Palm Oil Fuel Ash and Slag: Production of Environmental-Friendly Alkali Activated Mortars with Enhanced Properties. Construction and Building Materials. 170: 235-244.

[15] Huseien, G. F, Mirza, J., Ismail, M., Ghoshal, S. K. and Abdulameer Hussein, A. 2017. Geopolymer Mortars as Sustainable Repair Material: A Comprehensive Review. Renewable and Sustainable Energy Reviews. 80(C): 54-74.

[16] Cheah, C. B., Part, W. K. and Ramli, M. 2015. The Hybridizations of Coal Fly Ash and Wood Ash for the Fabrication of Low Alkalinity Geopolymer Load Bearing Block Cured at Ambient Temperature. Construction and Building Materials. 88: 41-55.

[17] Al-Homoud, M. S. 2005. Performance Characteristics and Practical Applications of Common Building Thermal Insulation Materials. Building and Environment. 40(3): 353366.

[18] Akinwonmi, A. S. 2012. Fracture Behaviour of Concrete with Sawdust Replacementunder Uniaxial Compressive Loading. International Journal of Innovative Research and Development. 1(9): 155-163.

[19] Bdeir, L. M. H. 2012. Study Some Mechanical Properties of Mortar with Sawdust as a Partially Replacement of Sand. Anbar Journal for Engineering Sciences. 5(1): 22-25.

[20] Nahak, A. and Dash, S. 2015. A Study on Strength of Concrete with Partial Replacement of Cement. International Journal of Engineering Research and Technology. 4: 134-137.

[21] Topçu, I. B. and Demir, A. 2007. Durability of Rubberized Mortar and Concrete. Journal of Materials in Civil Engineering .19(2: 173-178.

[22] Huseien, G. F., Mirza, J., Ismail, M., Hussin, M. W., Arrifin, M. A. M., \& Hussein, A. A. 2016. The Effect of Sodium Hydroxide Molarity and Other Parameters on Water Absorption of 
Geopolymer Mortars. Indian Journal of Science and Technology. 9(48): 1-7.

[23] Huseien, G. F., Mirza, J., Ismaila, M., Hussin, M. W., \& Ariffina, M. A. M. 2016. Potential Use Coconut Milk as Alternative to Alkali Solution for Geopolymer Production. Jurnal Teknologi. 78(11): 133-9.

[24] Huseien, G. F., Mirza, J., Ismail, M., Ghoshal, S. K., \& Ariffin, M. A. M. 2016. Effect of Metakaolin Replaced Granulated Blast
Furnace Slag on Fresh and Early Strength Properties of Geopolymer Mortar. Ain Shams Engineering Journal. 16: 110.

[25] Huseien, G. F., Sam, A. R. M., Mirza, J., Tahir, M. M., Asaad, M. A., Ismail, M., \& Shah, K. W. 2018. Waste Ceramic Powder Incorporated Alkali Activated Mortars Exposed to Elevated Temperatures: Performance Evaluation. Construction and Building Materials. 187: 307-317. 